\title{
Effect of Organic, Nitrogen and Potassium Fertilization Treatments on Growth, Yield and Chemical Contents of Two Cultivars of Potato (Solanum tuberosum)
}

\author{
Gehan A. Elsharkawy ${ }^{1}$
}

\begin{abstract}
Two field experiments were carried out at the Research farm, faculty of Agriculture, Alexandria University, during summer seasons of 2008 and 2009. The objective of the present study was to evaluate the response of two potato cultivars (valour and Lady Belfour) to different levels of poultry manure $(10$ and $20 \mathrm{m3} /$ fedan) and a combination of nitrogen and potassium mineral fertilizer $\{(0-0),(80-24),(120-48),(160-72)$ and (200- 96) $\mathrm{kg} \mathrm{N}-\mathrm{k}_{2} \mathrm{O} /$ fedan\}. The results showed that Lady Belfour had higher vegetative growth characters and higher chemical composition (protein content, tuber dry matter and $K$ content) in comparing to Valour. However, Valour exceeds Lady Belfour in yield component characters and in the percentage of large tubers. Concerning, the effect of poultry manure data indicating that $20 \mathrm{~m}^{3} /$ fed. showed superior effect on all vegetative growth characters, as well as, total tuber yield and its component. However, the response of higher rate of poultry manure didn't show a significant reflect on different tuber sizes and decrease the percentage of dry matter and starch content. It could be concluded that the best combination of mineral fertilizer which represent the highest total yield / fed and the highest percentage of large tubers is $160-72 \mathrm{~kg} \mathrm{~N}-\mathrm{K2O} / \mathrm{fed}$. in both growing seasons. However, the highest rate $200-96 \mathrm{~kg}$ $\mathrm{N}-\mathrm{K} 2 \mathrm{O}$ / fed. promoted the highest mean value of N,P,K and protein content. Valour cultivar showed superior performance in total yield / fed. when combined with either $20 \mathrm{~m}^{3} /$ fed or $160 \mathrm{~kg} \mathrm{~N}-\mathrm{K}_{2} \mathrm{O}$ / fed. The best organic mineral treatment combination on total yield was $20 \mathrm{~m} 3$ combined with $160 \mathrm{~kg} \mathrm{~N}-\mathrm{K}_{2} \mathrm{O}$. The results also, show a significant positive relationship between mineral fertilization and total yield of potato with a correlation coefficient reach to $95 \%$ and $96 \%$ in both growing seasons.
\end{abstract}

\section{INTRODUCTION}

Potato is one of the most important and favorite vegetable crop grown in the whole world. In Egypt the area cultivated with potatoes about 212,000 acres producing about 2.2 million tons, with an average of 10.5 tons per acre. Potato are grown in Egypt in a winter-spring cycle (planting from September to January and harvesting from March to early June) for early production. Potato has a high biological value because it is a rich source of starch, Protein and

\footnotetext{
${ }^{1}$ Department of vegetable crops, Faculty of agriculture,

Alexandria University

Received November 4, 2013, Accepted December 17, 2013
}

significant amount of vitamin $\mathrm{B}$ and $\mathrm{C}$ and minerals ( Kolb et al 1990).

The necessity of nitrogen, phosphorus and Potassium has been demonstrated by several investigators, since $\mathrm{N}$ supply was desirable for vegetative growth, dry matter accumulation as well as its significant role in the production and maintenance of an optimum plant canopy for continuous tuber growth throughout the growing season (Sharma and Grewal 1987). However, high amount of nitrogen augment the nitrates in tubers to levels above the threshold allowed by the major European distributers which in set at $200 \mathrm{mg} / \mathrm{kg}$ fresh weight (Ierna, 2009). Potassium stimulates early haulm growth and vigor as well as increases tuber size and yield (Allison et al. 2004 and EI-Sawy et al. 2000) Also, it has physiological processes in plant respiration, transpiration and translocation of sugars carbohydrates and enzyme transformation .

Large reduction in soil mineral must be compensated annually by good fertilization programs in order to maintain the high yield and good quality of potato in view of that, potato is one of the heavy feeders of plant nutrients (Albino 2008).

Application of organic fertilizers was found to improve structural stability and lowered bulk density of the soil. It improved moisture retention, water infiltration rate and the hydraulic conductivity of soil (Oiayinka, 1990) and (Aoyama et al. 1999) and also enhanced soil biological properties and soil fertility and led to increase in crop yield (Arriaga and Lowery 2003). Organic manure increase soil enzymatic activity which is responsible for forming stable organic molecules that contribute to the permanence of the soil ecosystem and for urease and phosphatase cycles (Gunapala and Scow 1998).

Environmental protection is one the priorities of the new objectives of global agricultural policy, a compromise between the need to maximize yield and profit and adequate use of fertilization rate is therefore required to reduce the impact of crop production on the environment

It has been reported that, combined application of both organic and inorganic give higher yield than is 
obtainable from applying either of them (Najm et al. 2010). Complementary use of two of them holds the key to sustainable agricultural productivity and has proved a sound fertility management strategy in many countries of the world. (Lombien et al (1991). In Egypt, national yield and variety trials data over several locations on different crop species clearly indicated that soil nutrient stress is the most significant factor controlling crop yield. Farmers should tackle this problem through the application of both organic and inorganic fertilizer which amends the soil environment.

The imported of new potato cultivars could reduce the price of imported common cultivars because the farmers in Egypt used to cultivate these cultivars every year so, the fits price was very expensive in the time of year, so it's see us wise to encourage the farmers to cultivate new cultivars which are similar in productivity (Elsharkawy and abdelaal 2013).

The objective of this research was to evaluate two promising new cultivars of potato that can respond to graded levels of nitrogen and potassium fertilizers under different levels of poultry manure application.

\section{MATERIALS AND METHODS}

Two field experiments were conducted at the Research Station Farm (Abies), faculty of Agriculture, Alexandria University. This sites lies between latitude $31^{\circ} 2 \mathrm{~N}$, and longitude $29^{\circ} 6 \mathrm{E}$ with an elevation of about $2.5 \mathrm{~m}$ below sea level. These experiments were carried during the two successive summer seasons of 2008 and 2009 to explore the influence of organic (poultry manure) and mineral $\mathrm{N}-\mathrm{K}$ fertilization treatment on the growth performance of two new varieties of potato Valour and Lady Belfour. Soil samples $(0-25 \mathrm{~cm})$ depth were collected before plant cultivation for analysis from the two experimental fields. These samples were analyzed for soil texture, organic matter available N, P, $\mathrm{K}$ and $\mathrm{PH}$ and EC according to (page et al., 1982). The obtained data are presented in (table 1).

\section{Preparation of poultry manure:-}

The poultry manure was stacked for 1 week under a shed to allow for mineralization. Sub- samples from this manure were used for the experiments and were analyzed to determine its nutrient composition (Table 2). The used Poultry manure were obtained from the Experimental Poultry Station, faculty of Agriculture, Alexandria University.

The Quantity of applied poultry manure used is divided into two rates 10 and $20 \mathrm{~m}^{3} / \mathrm{fed}$. These two rates are equivalent to 70 and $140 \mathrm{~kg} \mathrm{~N} /$ fed. respectively. The poultry manure were spread on the soil surface and immediately raved evenly for each plot and then mixed into the soil to a depth of $20 \mathrm{~cm}$ one week before planting.

Table 1. Some physical and chemical characteristic of the experimental soils

\begin{tabular}{|c|c|c|}
\hline Properties & Season 2008 & Season 2009 \\
\hline \multicolumn{3}{|l|}{ Physical properties } \\
\hline Clay \% & 46.1 & 39.6 \\
\hline Silt \% & 33.0 & 36.2 \\
\hline Sand $\%$ & 20.9 & 24.2 \\
\hline Soil texture \% & Clay loam & Clay loam \\
\hline \multicolumn{3}{|l|}{ Chemical properties: } \\
\hline *PH & 8.2 & 8.4 \\
\hline$* * \mathrm{EC}\left(\mathrm{dSm}^{-1}\right)$ & 3.38 & 3.34 \\
\hline \multicolumn{3}{|l|}{ Soluble cations (meq/l): } \\
\hline $\mathrm{Ca}++$ & 4.8 & 3.9 \\
\hline $\mathrm{Mg}+$ & 1.9 & 3.5 \\
\hline $\mathrm{K}+$ & 18 & 20 \\
\hline $\mathrm{Na}$ & 7.4 & 6.9 \\
\hline \multicolumn{3}{|l|}{ Soluble anions: } \\
\hline $\mathrm{CO}_{3}^{--}$ & 3.5 & 3.2 \\
\hline $\mathrm{HCO}_{3}^{-}$ & 1.9 & 1.8 \\
\hline $\mathrm{Cl}^{-}$ & 5.7 & 5.3 \\
\hline $\mathrm{SO}_{4}^{--}$ & 3.3 & 2.4 \\
\hline Total N\% & 0.16 & 0.18 \\
\hline Available phosphorus $\quad(\mathrm{ppm})$ & 31.5 & 31.8 \\
\hline
\end{tabular}

*measured in 1:25 soil water suspension.

**measured in the water extract of saturation soil paste. 
Table 2. Some physical and chemical analyses of poultry manure used in the field experiments

\begin{tabular}{lcc}
\hline Manure characteristics & $\mathbf{2 0 0 8}$ & $\mathbf{2 0 0 9}$ \\
\hline Moisture content (\%) & 41 & 36 \\
Weight of $1 \mathrm{~m}^{3}(\mathrm{~kg})$ & 465 & 355 \\
Ash (\%) & 38 & 20 \\
Organic mater (\%) & 61 & 84 \\
Organic carbon (\%) & 36 & 49 \\
Nitrogen (\%) & 1.43 & 1.89 \\
*pH & 7.8 & 6.9 \\
*Total dissolved salts (\%) & 0.33 & 0.23 \\
Macro-nutrient (\%) & & \\
**P & 2.06 & 1.85 \\
$\mathrm{~K}$ & 1.3 & 1.1 \\
$\mathrm{Ca}$ & 0.34 & 0.51 \\
$\mathrm{Mg}$ & 0.12 & 0.10 \\
$\mathrm{Na}$ & 0.40 & 0.17 \\
$\mathrm{Micro}-$ nutrient (ppm) & & \\
$\mathrm{Fe}$ & 14.9 & 20.3 \\
$\mathrm{Mn}$ & 5.3 & 23.4 \\
$\mathrm{Zn}$ & 9.9 & 20.0 \\
$\mathrm{Cu}$ & 5.5 & 17.0 \\
\hline
\end{tabular}

* (1:10 w:v) poultry manure : water ratio.

** Total P content was determined using wet digestion.

\section{Inorganic mineral $\mathbf{N}$ - K fertilization:-}

A combination of five N-K levels were used $(80-$ 24), (120-48), (160-72) and (200-96) $\mathrm{kg} \mathrm{N}-\mathrm{K}_{2} \mathrm{O} / \mathrm{fed}^{-1}$ in addition to zero levels of both elements as a control treatment. The source of mineral fertilizers were ammonium nitrate $\left(\mathrm{NH}_{4} \mathrm{NO}_{3}, 33.5 \%\right)$ and potassium sulphate $\left(\mathrm{k}_{2} \mathrm{So}_{4}, 48 \% \mathrm{k}_{20}\right)$. One third of $\mathrm{N}-\mathrm{K}$ fertilizers were added in the first period of growth (40-50 day from planting). The two third of $\mathrm{N}-\mathrm{K}$ were divided into four equal portions and side dressed at 10 days intervals. The mineral $\mathrm{N}$ and $\mathrm{K}_{2} \mathrm{O}$ fertilizer were added manually in each plot after weed control, then the soil was immediately irrigated. Moreover, super phosphate fertilizer $\left(18.5 \% \mathrm{p}_{2} \mathrm{O}_{5}\right)$ was applied to the experimental plots as a basal dose during soil preparation at a rate of $50 \mathrm{~kg} \mathrm{P}_{2} \mathrm{O}_{5} /$ fed.

\section{Potato cultivars used:-}

Imported seeds of two potato varieties valour and lady Belfour kindly obtained from Agro Food Company, Cairo-Alex. Desert road, Egypt were used in this study. Virus-free seed tubers of the both cultivars were always cut lengthwise to ensure an equal number of buds per tuber seed unit. The tubers were spread in a well-ventilated room and covered with a single layer of jute Saks to initiate fast sprouting under diffused light. The tubers were protected against fungal attack by dusting them with a mixture of ash powder containing $45 \%$ Diathane M- 45 .

\section{Experimental layout:-}

The experimental layout was a split-split-plots systems in randomized complete block design (RCBD) with three replications. The two cultivars of potato (Valour and Lady Belfour) were arranged as the main plots, while, poultry manure application rates were (10 and $20 \mathrm{~m}^{3} /$ fedan) were considered as sub plots. However, mineral N-K fertilizer application $((0-0),(80-$ $24),(120-48),(160-72)$ and (200-96) $\left.\mathrm{Kg} \mathrm{N}-\mathrm{K}_{2} \mathrm{O} / \mathrm{fed}^{-1}\right)$ were placed in the sub-sub-plots. Each sub-sub plot consisted of 5 ridges each was $4 \mathrm{~m}$ length and $75 \mathrm{~cm}$ width with an area of $15 \mathrm{~m}^{2}$ A guard ridge was left between each adjacent main plots. Planting was carried out on 15 and 20 February for 2008 and 2009 trials ,respectively.

During the two growing seasons, weed control was carried out by hand holing Pest control, irrigation and other agricultural Practices were achieved wherever they found necessary and as recommended for the commercial potato production, the crop were harvested when the leaves turned yellow and senescent indicating full maturity. Harvesting dates were 29 May 2008 and $4^{\text {th }}$ of June 2009.

\section{Data recorded:}

\section{1- Vegetative growth characters:}

Random samples of ten plants were taken from each plot at 85 days after planting (complete tuber formation) for measuring plant height $(\mathrm{cm})$, no. of branches, foliage weight (gm/ plant) and leaf area $\left(\mathrm{cm}^{2} /\right.$ plant).

2- yield and yield component: 
The same selected plants were taken from each plot at 85 days after planting (complete tuber formation) for measuring No of tubers / plant, weight of tubers gm / plant, average tuber weight $(\mathrm{gm})$, Tuber diameter $(\mathrm{cm})$.

At harvest time 105 to 110 days after planting total yield / plot were counted, weighted and ranked for their marketability and size and converted to tons / fedan. Tuber grading for the yield of each plot was graded into three sizes: small (less than $30 \mathrm{~mm}$ ), medium (30$60 \mathrm{~mm})$ and large over $(60 \mathrm{~mm})$ in diameter. The weight of each grade was obtained and the percentage of each grade was calculated.

\section{3- Chemical constituents:}

Dry matter content in tubers (\%),crude protein content $\%$, total sugars $\%$, starch $\%$ as well as determination of total $\mathrm{N} \%$, total $\mathrm{P} \%$ and total $\mathrm{K}$ (ppm)content in tubers were also measured using standard methods of (AOAC 1995).

\section{Statistical analysis:-}

Data were analyzed using co-stat software computer program for statistics (2004). The differences among the means of the experimental treatments were separated by revised L.S.D test for interpretation of results as explained by steel and torrie. (1980).

\section{RESULTS AND DISCUSSION}

\section{I: Main effect of the different studied parameters:- Vegetative growth characters:-}

Table (3) showed the presence of a significant difference between the used tow studied potato cultivars with respect to foliage plant weight, plant height No. of branches / plant and leaf area . However, in the case of plant height in the second season the difference did not reach the significance level. It was noticed generally that lady Belfour showed higher values of all studied vegetative growth characters comparing to valour in both studied seasons. This results are attributed by those obtained by (Elsharkawy and Abdelaal 2013) who demonstrated that lady Belfour exceed valour in vegetative growth characters under two different locations.

Application of $20 \mathrm{~m}^{3}$ /fedan of poultry manure gave the highest significant value for no. of branches, foliage weight and leaf area/ plant in both seasons and showed a significant difference comparing to $10 \mathrm{~m}^{3}$ poultry manure. However, the detected increment were not high enough to reach the level of significance for plant height in both season.table (3). The superior effect of high rate of poultry manure might be attributed to the fact that poultry manure contains essential mineral nutrients such as $\mathrm{N}, \mathrm{P}, \mathrm{K}$. as well as micronutrients, and provides decomposable organic matter thereby increasing soil aggregation which in turn improves physico-chemical condition of the soil such as water holding capacity. In addition the carbon content in the manure can be utilized as food by soil microorganism, which increases microbial activity to convert unavailable plant nutrients to available forms through biological transformation (mineralization) (Arriaga and Lowery 2003). This preparets of manure may have promoted potato vegetative growth in this experiment.

Concerning the effect of mineral $\mathrm{N}-\mathrm{K}$ levels on vegetative growth table (3) data revealed that the gradual increment of mineral N-K application resulted in significant increase for foliage plant weight and leaf area in both seasons compared with the control, whereas, plant height and no. of branches / plant not significantly affected in both seasons. The highest plants weight and the maximum leaf area/plant were produced with the highest fertilizer rate $(200 \mathrm{~kg} \mathrm{~N}$.fed$96 \mathrm{~kg} \mathrm{k}_{2} \mathrm{o} / \mathrm{fed}$ ) which was significantly not different from that produced by the next lower rate $(160 \mathrm{~kg} \mathrm{~N} /$ fed$72 \mathrm{~kg} \mathrm{k} \mathrm{k}_{2} \mathrm{O} / \mathrm{fed}$ ) in the first season whereas, in the second season foliage weight and leaf area increased by application of $\left(160 \mathrm{~kg} \mathrm{~N} /\right.$ fed-72kg k $\left.\mathrm{k}_{2} \mathrm{O} / \mathrm{fed}\right)$ beyond which no significant increase was recorded. This might be due to the relatively low amount of available $\mathrm{N}$ in the used soil in the first season (table 1). The necessity of $\mathrm{N}$ and $\mathrm{K}$ for potato growth has been demonstrated by several investigator since nitrogen supply was desirable for vegetative growth, dry matter as well as nutrient uptake by potato plants(Ierna et al 2011 ), (Mauromical et al., 2003), (Albino et al. 2008) and (Eliwa et al 2012). The increase in plant growth (Table 3)may be attributed to the beneficial effects of nitrogen as stimulating the meristimatic activity for producing more tissue and organs, in addition to its vital contribution in several bio chemical processes that related to plant growth (Marschner, 1995).

The obtained results of growth parameters in this investigation are in good agreement with these obtained Eliwa et al. 2012, Ierna2009, Albino et al. 2008 and Agbede 2010.

\section{Yield and its component:-}

Data in table (4) indicated that valour c.v gave significantly the higher total tuber yield (11.43 and 13.56 ton/fed), the higher tuber weight / plant (632and $678.5 \mathrm{gm} / \mathrm{plant}$ ) and the bigger average tuber weight (71.01and 91.1gm) compared with lady Belfour one (8.98and 11.28ton/fed), (533.6and 603gm/plant)and (62.09 and 85-77), in the two growing seasons respectively. Valour was higher by above $(+21.4 \%$ and $16.81 \%$ ) compared with c.v lady Belfour in relation to total yield in both seasons. However, the difference between the two cultivars in number of tubers plant and 
tuber diameter did not reflect any significant difference. The genetic variation could be responsible for valour having relatively larger tubers than lady Belfour. Elsharkawy and Abdelaal 2013 confirmed the superiority of valour in tuber yield characters under two different locations. The same genetic variation was earlier observed by Babaji et al. (2009). It could be concluded that, the largest potato total yield was achieved owing to the increase in average tuber weight rather than tuber number/plant. Babji et al. 2009 confirmed that Greta potato cultivar had larger tubers and lower proportion of unmarketable tubers comparing with Nicola, RC-767-2 and wc-732-1.

Results for tuber size grading by percentage in terms of weight for the both studied cultivars is presented in (Fig.3) the results showed that the higher portion of large tubers was found in valour $36 \%$ and $49 \%$ comparing with lady Belfour c.v. (30.29\% and $44.46 \%$ ) in both growing season, respectively whereas, lady Belfour detected the highest percentage of small tubers (13.52\% and 29.58\%) compared with valour $(6.91 \%$ and $17.06 \%)$ in both season, respectively fig (3). It was noticed also that percentage of medium tubers occupied the greater percentage by both cultivars but the trend of influence were however statistically insignificant. This results are in agreement with those reported by Babaji et al. 2009 and Albino et al. 2008.

The result in table (4) showed that, increasing the applied rates of poultry manure up to $20 \mathrm{~m}^{3} / \mathrm{fed}$ led to progressive significant increase in the mean value of the following characters: No of tubers / plant, tuber weight/ plant, Average tuber weight (in the second season) and total yield, compared with $10 \mathrm{~m}^{3}$ poultry manure application. The increase percentage on total tuber yield by the highest organic level $20 \mathrm{~m}^{3} /$ fed compared with the lower level $10 \mathrm{~m}^{3} /$ fed., were $38 \%$ and $48 \%$ in both growing seasons, respectively. However tuber diameter did not show any significant differences between the two organic manure level.

Although, addition of poultry manure with the higher rate has a superior reflect on total yield of potato. Results for tuber size categories were not clear enough and show relatively little and insignificant variation between both chicken manure rates. These results of the superiority of high rate of poultry manure on potato yield component are also in conformity with the findings of Agbede 2010 who indicates that crop grown for their roots and tubers benefit from organic manure not only as a source of nutrients but also as a room for good root extension and tuber bulking. Worldwide, manure has been used as a source of organic matter $\%$ to improve soil bulk density creating conductive environment for crops like potato Arriage and Lowery
2003, microbial biomass and activity Guanapula and scow 1998.

The effect of a combination between nitrogen and potassium rates were found highly significant on yield parameters such as, tuber number / plant in the second season, tuber weight/ plant, average tuber weight, tuber diameter, total yield and percentage of the different categories of tuber size as presented in table (4) and (fig3). It could be concluded generally that the influence of $\mathrm{N}-\mathrm{K}_{2} \mathrm{O}$ application varied between the two seasons. In summer season of 2008, increasing the application rates of $\mathrm{N}-\mathrm{K}_{2} \mathrm{O}$ from 0 to $200-96 \mathrm{~kg} \mathrm{~N}-\mathrm{K}_{2} \mathrm{O}$ resulted in gradual increasing of total tuber yield from 8.43 to 11.08 ton/fed. with relative increase of $31.43 \%$ relative to control. However, in 2009 increasing $\mathrm{N}-\mathrm{K}_{2} \mathrm{O}$ rates up to favorable point increased tuber yield per unit area. The highest value of tuber yield was obtained at 120-48 and $160-72 \mathrm{~kg} \mathrm{~N}-\mathrm{K}_{2} \mathrm{O} /$ fed. Without a significant difference between them with increment level reach to $51.2 \%$ and beyond this at the highest rate of N-K levels a significant reduction was measured. This might be due to the relatively low available amount of the total $\mathrm{N}$ in the used soil in the first season (table 1). The effect of $\mathrm{N}-\mathrm{K}_{2} \mathrm{O}$ levels on no of tubers/plant and weight of tubers/plant followed the same pattern of significance and presented the same picture as total yield/fed. in each year. This is due to the fact that, increase concentration of nitrogen fertilizer can increase the nitrogen uptake and this increase has a positive effect on chlorophyll concentration, photosynthetic rate, leaf expansion, total number of leaves and dry matter accumulation. Consequently nitrogen fertilizer plays an important role in trigger canopy development especially on the shoot dry matter\% which, will reffect obn total tuber yield. (Nejm et al. 2010. The $200-96 \mathrm{~N}-\mathrm{K}_{2} \mathrm{O}$ gave the highest percentage of large tubers $39 \%$ and $49 \%$ (fig 3) though there was no significant variation between N160 and N120 and N200. The lowest no of large tubers 28\% were found from control. Identical trend with higher magnitude were also observed in medium tubers without significant difference in both years. The highest percentage in small tubers was obtained from control and the lowest from $200-96 \mathrm{~kg} \mathrm{~N}-\mathrm{K}_{2} 0 \mathrm{~kg} / \mathrm{fed}$. That was statistically similar with other $\mathrm{N}-\mathrm{K}_{2} \mathrm{O}$ levels. Our results pointed to the convenience medium level of fertilization corresponding to the crop uptake, thus allowing savings with respect to the high levels $200-96 \mathrm{~kg} /$ fed $\mathrm{N}-\mathrm{K}_{2} \mathrm{O}$ Ierna et al. 2011. These results concur with several authors in fertilization of potato Ferrieira and Corr 2002. On contrary, Mohammed et al. 1999 reported that in Jordan that in a trial using the cultivar Spunta, fresh tubers were not significantly influenced by applying nitrogen from 49 to $98 \mathrm{~kg} \mathrm{ha}^{-1}$. 


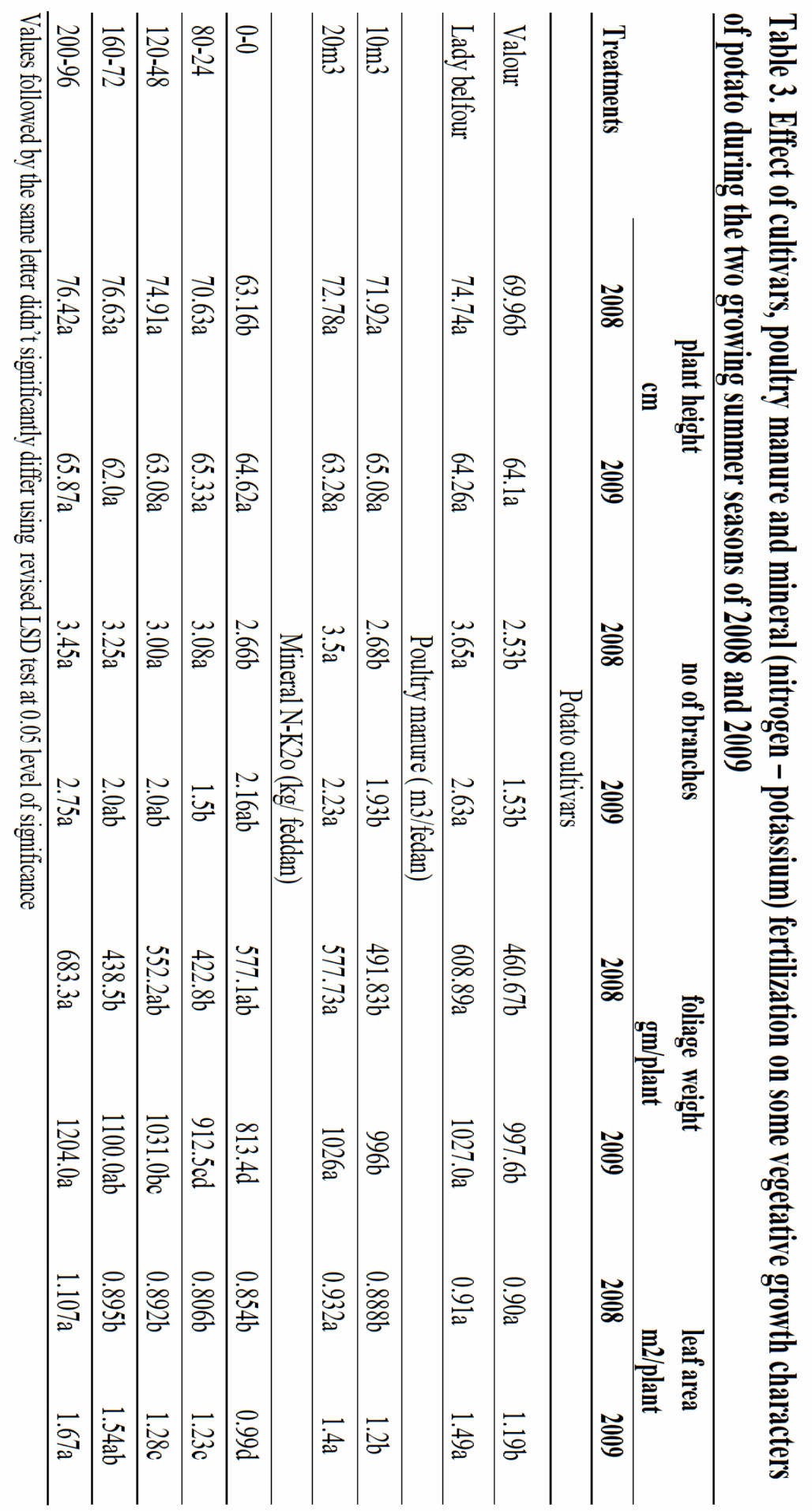




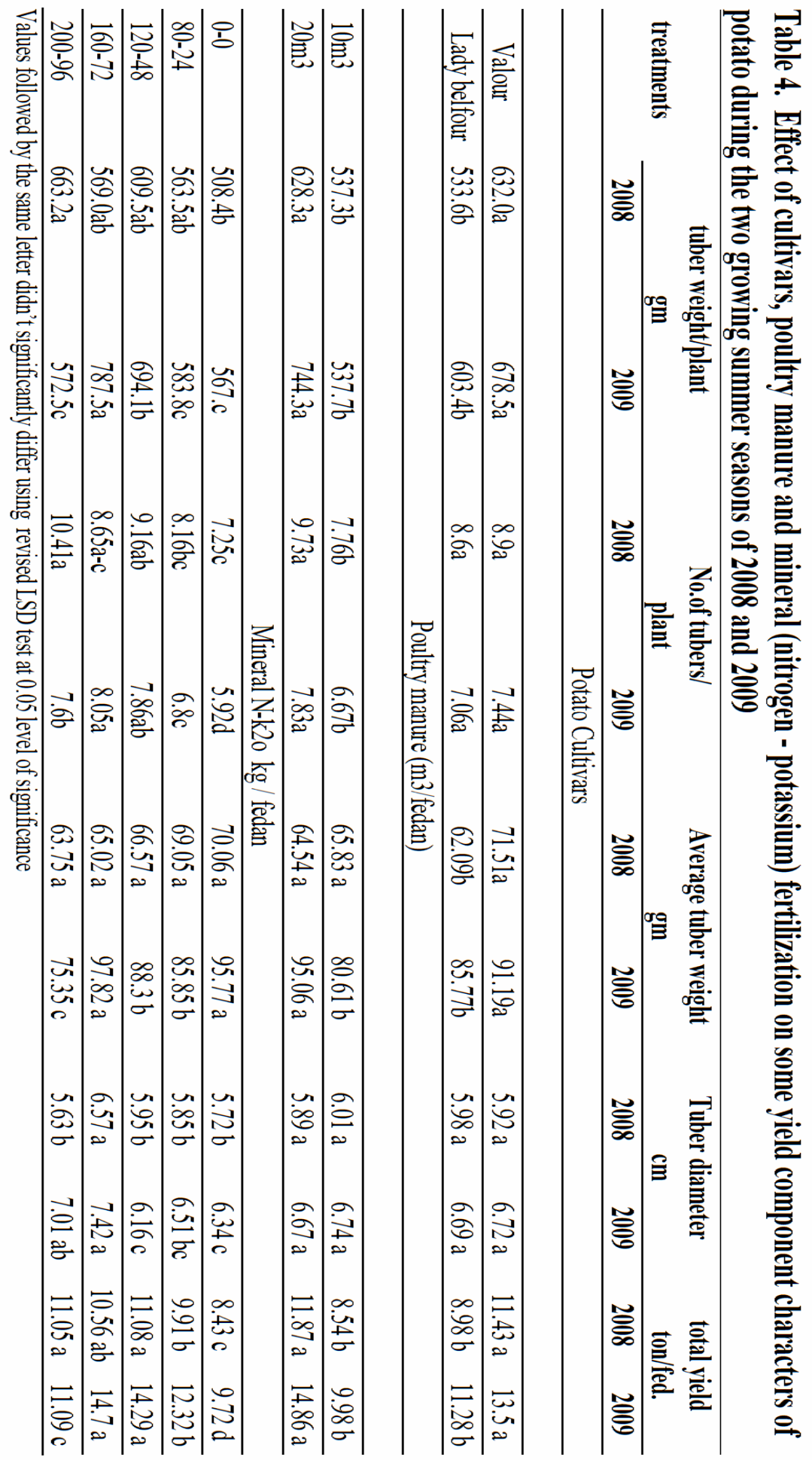




\section{Chemical Composition of potato tubers:}

The difference between Valour and Lady Belfour for their mineral composition and some tuber quality parameters are presented in table (5). The results indicate that lady Belfour exceed Valour significantly in tuber protein content and, tuber dry matter and $\mathrm{K}$ content. However, the difference was insignificant for starch $\mathrm{P}$, and $\mathrm{N}$ content in the tubers.

Concerning, the effect of poultry manure rates on $\mathrm{N}, \mathrm{P}$, total sugar, protein, starch and tuber dry matter, table (5) showed that increased poultry manure rates up to $20 \mathrm{~m}^{3} /$ fed. was associated with detected increment in $\mathrm{N}$ and protein content. However, application of poultry manure reduced the percentage of dry matter and starch content. The detected difference in $\mathrm{P}$ content $\mathrm{K}$ content and percentage of total sugar content did not show any significant difference between the two levels of poultry manure.

The beneficial effect of organic may be due to an increase in organic matter rate caused by the generation of carbon dioxide during manure decomposition and improvement of the soil structure conditions which encourage the plant to have a good root development by improving the aeration of the soil Arriaga and Lowery 2003 and EI-Sawy et al. 2000.

Table (5) showed that application of combination mineral $\mathrm{N}-\mathrm{K}_{2} \mathrm{O}$ fertilizer at the rate of $200-96 \mathrm{~kg} \mathrm{~N}-\mathrm{K}_{2} \mathrm{O}$ $\mathrm{kg} /$ fed. gave significantly higher mean values of $\mathrm{N}, \mathrm{P}$, $\mathrm{k} 20$ and protein contents.

The results illustrated also that, application of N-K fertilizer with successive amounts caused some significant decrease in $\%$ of dry matter and $\%$ of starch.

Dry matter decreased may be due to dilution effect that associated with K-level increased. Similar observation are obtained by Allison 2006 who observed that $\mathrm{K}$ addition significantly decreased dry matter $\%$ in tuber yield.

\section{Interactions effect between different treatments on some potato yield and quality characters:}

First order interaction for some important characters of potato production like, number of tuber/ plant, weight of tubers/ plant, average tuber weight, total yield ton/fed. and percentage of tuber dry matter are presented in Table (6) and Fig 1. The interaction effect between potato cultivars and rates of chicken manure showed that the highest yield of potato which had the largest number of tubers and highest tuber weight/ plant were associated with using high level of poultry manure $\left(20 \mathrm{~m}^{3} /\right.$ fed.) and either cultivars Valour or Lady Belfour with preference to Valour which had the higher percentage of large tubers. Concerning, tuber chemical composition it could be concluded generally that lady Belfour had higher of tuber dry matter, protein and starch content without a significance difference in case of starch.

The interaction effect between both tested potato cultivars and mineral $\mathrm{N}-\mathrm{K}_{2} \mathrm{O}$ fertilizer reflected fluctuated influence on total yield and its component in the two seasons of experiment (Fig 1 and Table 6-). It could be concluded that the performance of lady Belfour was better in second growing season than in the first which reflect instability of this cultivar. The highest yield was recorded by Valour (or Lady Belfour in second season only) when each supplied with 160$72 \mathrm{~kg} \mathrm{~N}-\mathrm{K} 20 /$ fed. while the lowest tubers yield were produced by lady Belfour when no fertilizer were applied.

Further increase in fertilizer level up to $200-96 \mathrm{~kg}$ $\mathrm{N}-\mathrm{K}_{2} \mathrm{O} /$ fed. depressed tuber yield for both cultivars in both seasons. It is interesting to note that increasing $\mathrm{N}$ $\mathrm{K}$ fertilizer rate from 0 to $(200-96) \mathrm{kg} \mathrm{N}-\mathrm{K}_{20} /$ fed. significantly increased gradually tuber protein content in both cultivars and in both seasons. However, increasing N-K20 levels gradually decreased tuber dry matter in both cultivars. The $\%$ of starch content in Valour were affected by increasing N-K levels with a higher magnitude than lady Belfour did.

Concerning, the first order interaction effects, among the different rates of organic- and mineral- $\mathrm{N}$ fertilizers on some yield and quality characters of potato tubers are shown in (Fig 2). The comparison among the means of the 10 treatment combination revealed that, the highest yield was obtained when $20 \mathrm{~m} 3 /$ fed. poultry manure and 120-48 kg N-K/fed or 160-72 kg N-K/fed were applied in combination without any significant difference the percentage of increment reach up to $79 \%$ and $175 \%$ in both growing seasons comparing to control .The effect of interaction between organic and inorganic fertilization was significant on protein content. This could be related to the vital role of $\mathrm{K}$ in plant that associated directly and indirectly with protein synthases .Such effect of interaction is in agreement with results that obtained by Elsawy et al. 2000 .

Fig (4) showed the relationship between gradual rates of mineral fertilization and yield of potato in both years 2008 and 2009. The results showed that a small increase in mineral fertilizer caused a considerable increase in potato tuber yield in the present work. The equation relating to the tuber yield of potato values $\mathrm{Y}$ and the different added rates of $\mathrm{N}-\mathrm{K} 2 \mathrm{O}$ mineral fertilizer under both poultry manure rates for 


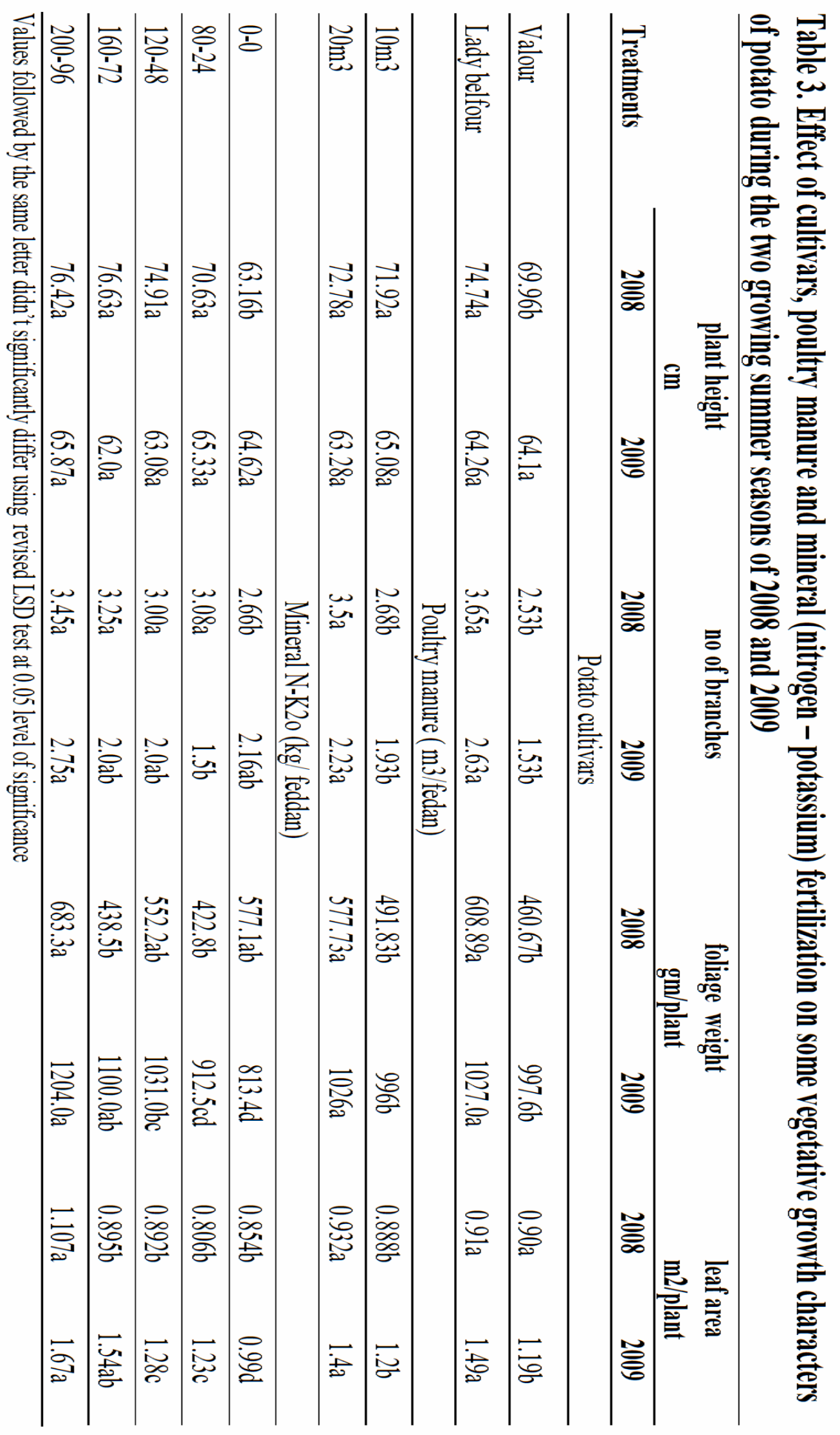




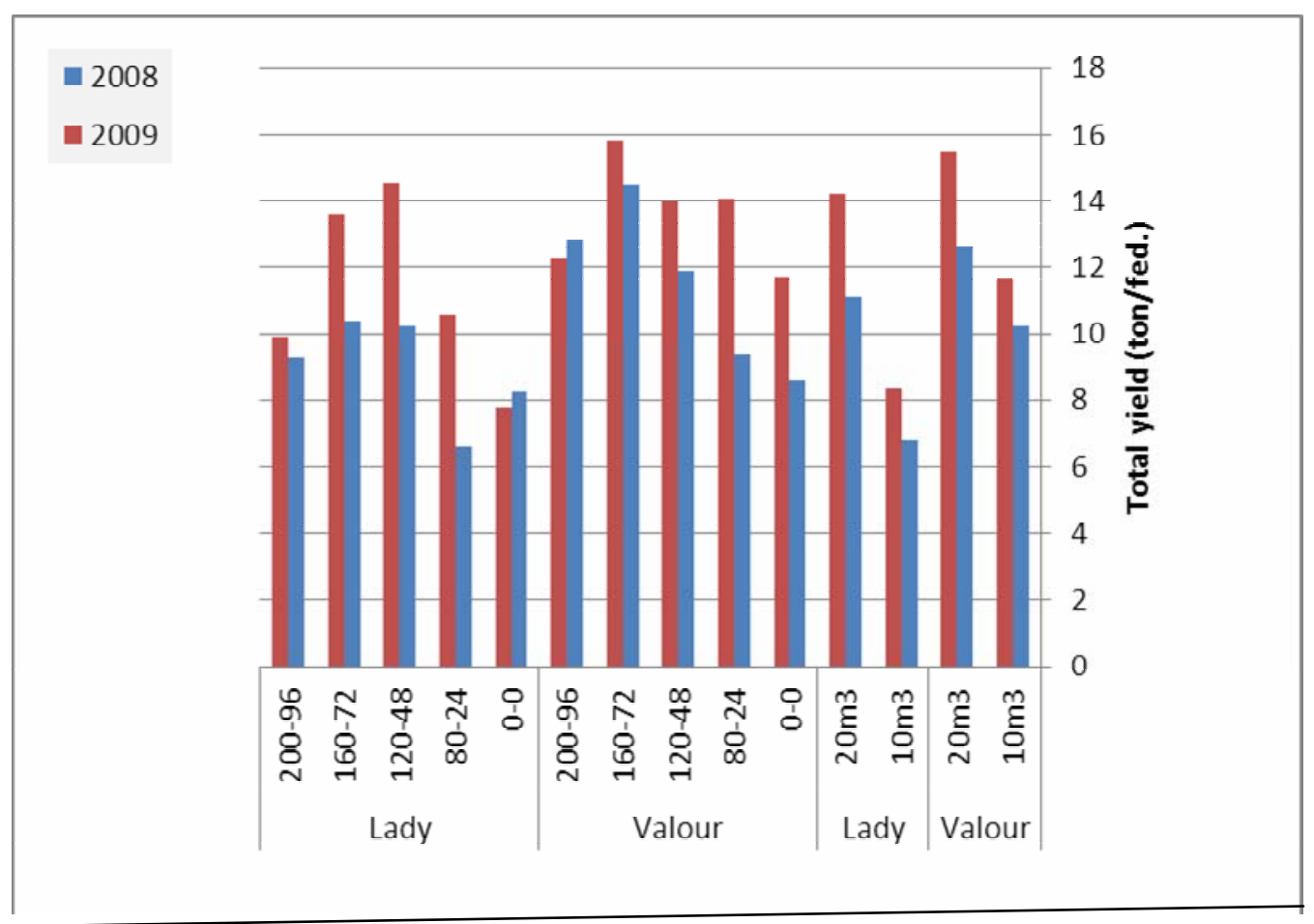

Fig. 1. Total yield per fedan of potato tubers as affected by interaction between cultivars and poultry manurine, mineral $\mathrm{N}-\mathrm{K}_{2} \mathrm{o}$ levels in seasons 2008 and 2009

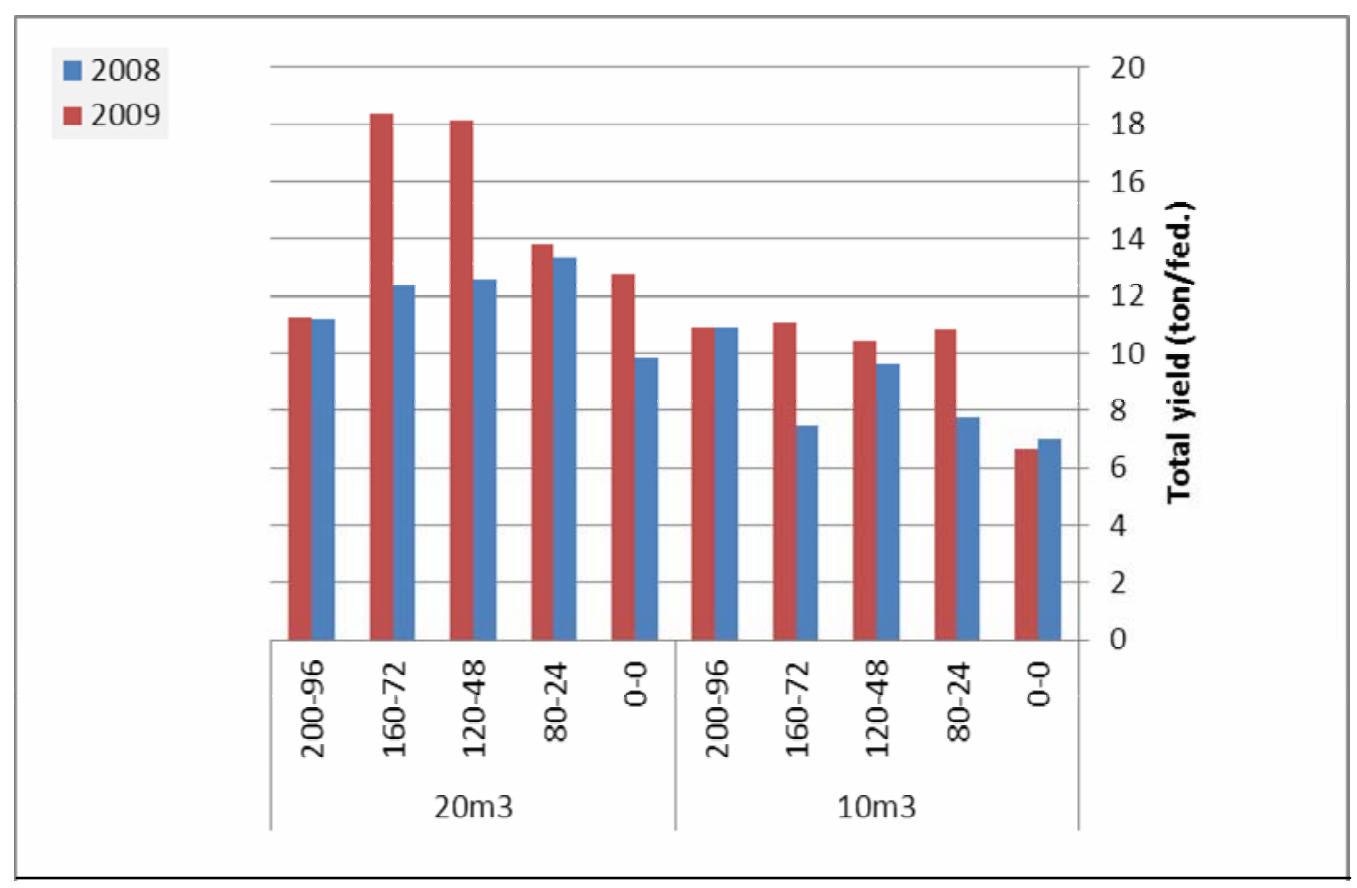

Fig. 2. Total yield per fedan of potato tubers as affected by interaction between poultry manurine and mineral $\mathrm{N}-\mathrm{K}_{2} \mathrm{O}$ levels in seasons 2008 and 2009 


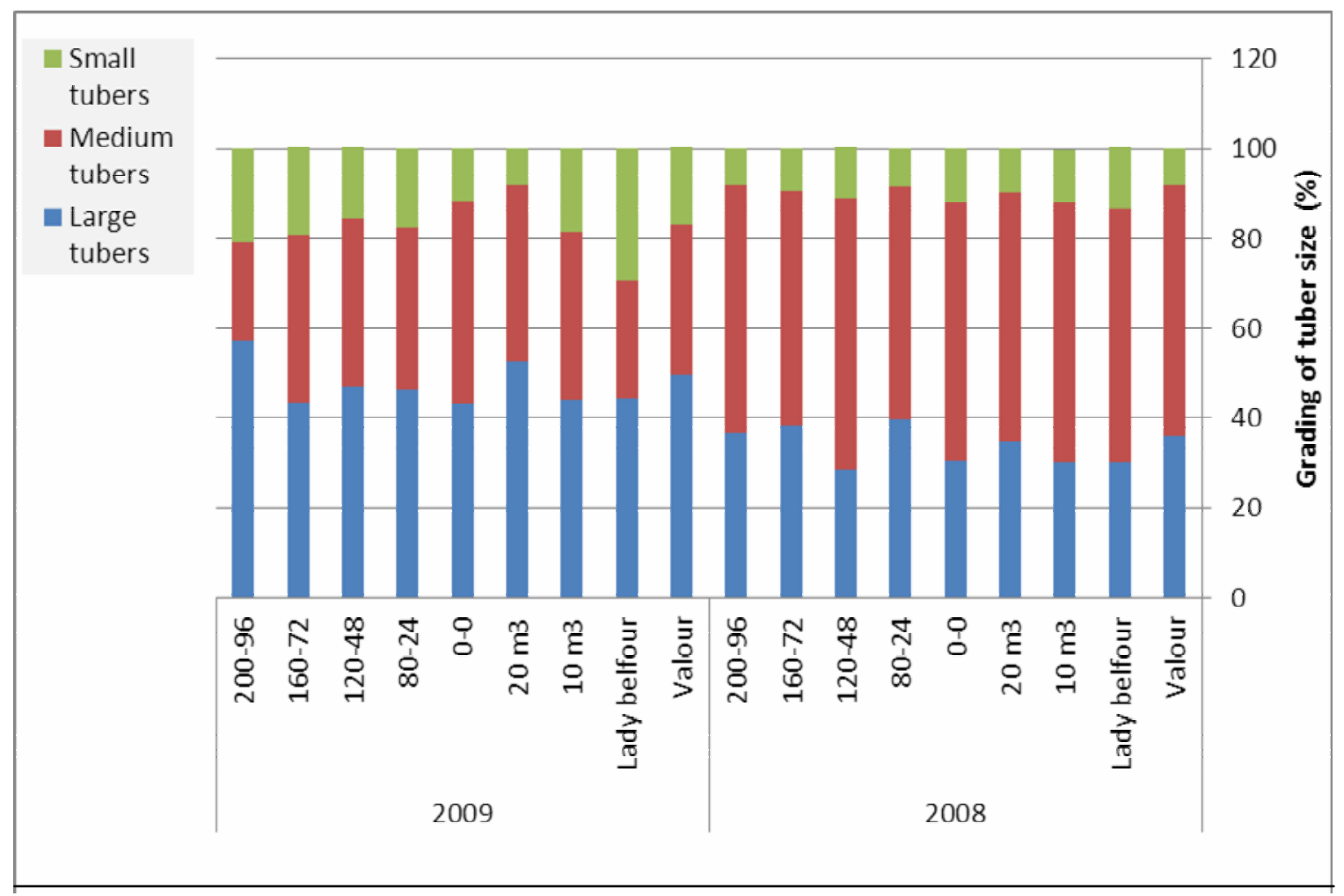

Fig. 3. Grading of potato tubers as affected by all interaction between cultivars, poultry manurine and mineral $\mathrm{N}-\mathrm{K}_{2} \mathrm{O}$ levels in seasons 2008 and 2009

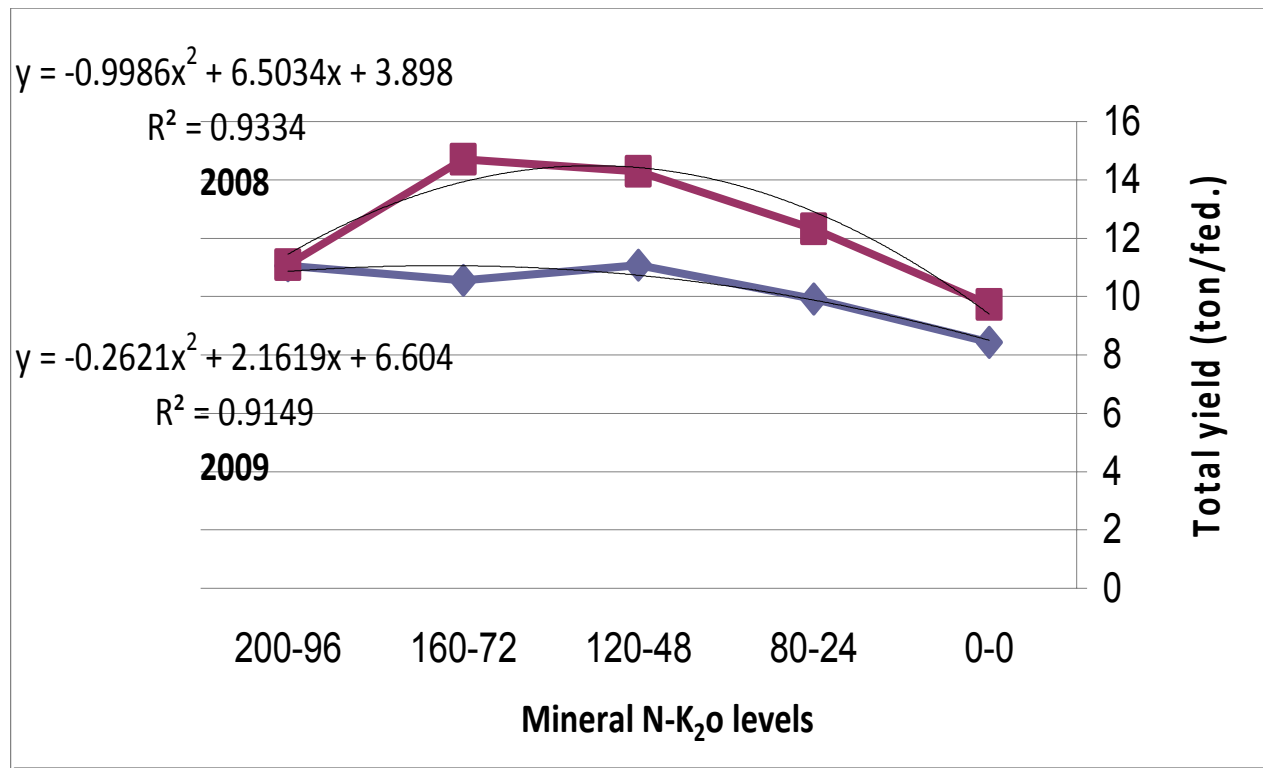

Fig. 4. Relationship between total yield per fedan of potato tubers and mineral $\mathrm{N}-\mathrm{K}_{2} \mathrm{o}$ levels in seasons 2008 and 2009 
Valour and Lady Belfour were $\mathrm{Y}=-0.99 \mathrm{x} 2+6.5 \mathrm{x}+$ 3.89 in 2008 and $\mathrm{Y}=0.26 \mathrm{x} 2+2.16 \mathrm{x}+6.6$ in 2009 season. There were significant positive relationships between mineral fertilizer and potato yield with correlation coefficient reach $\mathrm{R} 2=0.93$ and $\mathrm{R} 2=0.91$, in both growing seasons, respectively. (Ierna 2010.and Agbede 2010).

\section{REFERENCES}

A. O. A. C. (2000). Association of official Agricultural chemists. Official Methods of Analysis 17thed, AOAC, Washington DC, USA. pp. 13-15

Agbede, T.M. 2010. Tillage and fertilizer effects on some soil properties, leaf nutrients concentrations, growth and sweet potato yield on an Alfisol in southwestern Nigeria. Soil \&Tillage Res. 110:25-32.

Albino, M., P. Carillo, G. S. Bulmetti , A. F. G. Barbieri and S. De Pascale. 2008. Potato yield and metabolic profiling under conventional and organic farming. Europ. Jour. Agronomy. 28:343-350.

Allison, M.F., J.H. Fowler and E.J. Allen, 2004. Responses of potato (Solanum tubersum L) to potassium fertilizers. J. of Agric. Sci., 136(4): 407-426.

Aoyama, M., D. A. Angers, A. N'Dayegamiye, and N Bissonnette,1999. Protected organic matter in water-stable aggregates as affected by fertilizer and manure applications. Can. J. Soil Sci., 79:419-425.

Arriaga JF, Lowery B (2003). Soil physical properties and crop productivity of an eroded soil amended with cattle manure. J Soil Sci., 168: 888-899.

Babaji, B.A., E. B. Amans, U.F. Chiezey, A.M. Falaki, B. Tanimu and A.A. Mukhtar. 2009. Unmarketable tuber yield and other agronomic parameters of four varieties of irish potato as influenced by NPK fertilizer rate and type of seed tuber. Asian jour. Of Crop Sci.1(1):26-33.

Eliwa, E.Mona, S. A. Ibrahim, and M. F. Mohamed.2012. Combined effect of NPK levels and foliar nutritional compounds on growth and yield parameters of potato plants.African Jour. Of Microbiology Res. 6(24):51005109.

EI-Sawy, B.I., E.A. Radawan and N.A. Hassan, 2000. Growth and yield of potato as affected by soil and foliar potassium application. J. Agric. Sci. Mansoura Univ., 25(9): 58435850 .

El-Sharkawy, A. Gehan and Hala A. Abdel-AaL 2013. Detection of genotype $\times$ environment interaction for some potato (solanum tuberosum) cultivars evaluated across environment. Assian Journal of Crop Science.

Ferreira, T:C ., Carr, M.K. V" 2002. Responses of potatoes (Solanumtuberosum L) to irrigation and nitrogen in a hot, dry climate. I. Water use. Field Crops Res. 78. 51-64.
Fontes. P.CR.,Braun. H., Busato, C ., Cecon. P, R., 2010. Economic optimum nitrogen fertilization rate effects on tuber characteristics of potato cultivars, Potato Res. 53. 167-179.

Gunapala N, and Scow K (1998). Dynamics of soil microbial and activity in conventional and organic farming systems. Soil Biol.,30:-805-816

Ierna, A,. 2010. Tuber Yield and quality characteristics of potatoes for off-season crops in a Mediterranean environment. j, Sci. Food Agric. 90. 85-90.

Ierna. A. 2009. Influence of harvest date on nitrate contents of three potato varieties for off-season production. j. Food compos. Anal. 22. 551-555.

Ierna ,A ,G.Pandino, S. Lombardo, G. Moauromical. 2011. Tuber yield, water and fertilizer productivity in early potato as affected by a combination of irrigation and fertilization. Agric. Water Management. 101: 35-41.

Kolbe H, Zhang Wl, BaliGer 1 (1990). Simulation of fertilizer influence on yield and quality of potato (Solanuntuberosum) tubers by non linear optimization method. Plant Soi, 124: 309-313.

Lombin, LG., Adepetu, j.A., Ayotade, A.K., 1991. Organic Fertilizer in the Nigerian Agriculture: Present and Future. FPDD, Abuja, pp. 146-162.

Love, S. L., Stark, J.C., Salaiz. T., 2005. Response of four potato cultivar to rate and timing of nitrogen fertilization. Am. Potato J.82, 21-30.

Mauromicale. G ., Signorelli, p., lerna. A. Foti,. S" 2003. Effects of intraspecific compe- tition on yield of early potato grown in Mediterranean environment. Am. Potato J. 80,281-288

Marschner H (1995). Mineral nutrition of higher plants. 2nd Ed. Academic. Press. London New York, p. 889.

Mohammad, M.J., Zuraiqi, S .,Quasmeh. W., Papadopoulos. I., 1999. Yield response and nitrogen utilization efficiency by drip-irrigated potato. Nutr. Cycl. Agroe- cosyst. 54 . 243-249.

Najm, M. R. Haj SeyedHadi, F. Fazeli, M. TaghiDarzi, R. Shamorady, 2010.Effect of utilization of organic and inorganic nitrogen source on the potato shoots dry matter, leaf area index and plant height, during middle stage of growth. International Journal of Agricultural and Biological Sciences, 1: 26-29.

Oiayinka, A, 1990. Effects of poultry manure, corn straw and sawdust on plant growth and soil chemical properties. Ife journal of Agriculture 12, 36-44.

Page, A. L. 1982. Methods of soil analysis, part 2 : chemical and microbiological properties. Amer. Soc. Agron., Madison, Wisconsin, USA.

Sharma, R. C. and J. S. Grewal. 1987. Efficient use .of urea for potatoes grown on acidic brown hill Soils of Simla. J. Indian Potato Assoc., 5: 141-150 


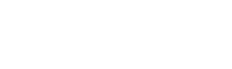

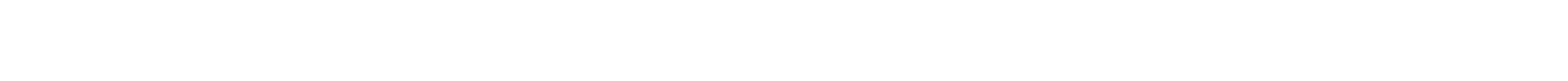 من البلالس البالن}

جيهن عبد الهزي الثرقاوي

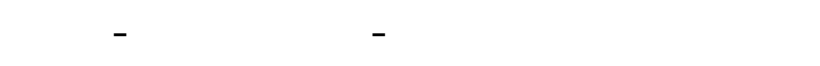
للفنل اعلى قيمة للمساهة الورقية والوزن الطازج خلا عاله لهي

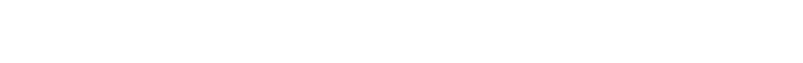

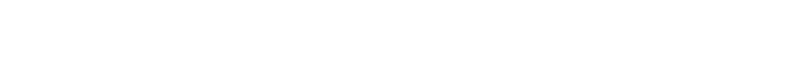

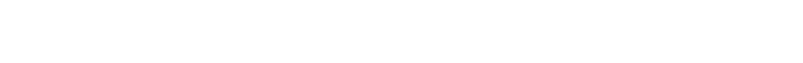

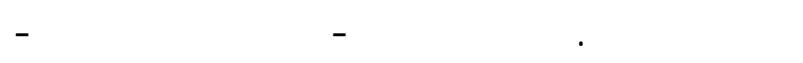

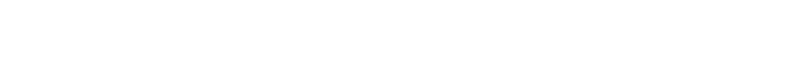

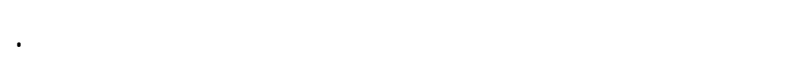

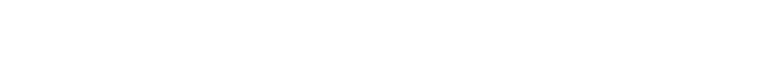

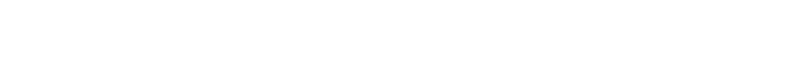

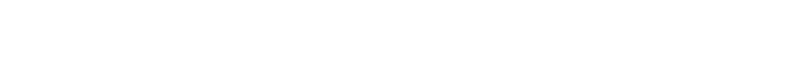

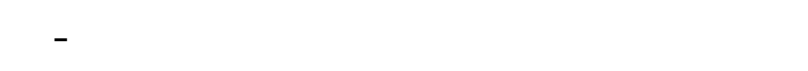

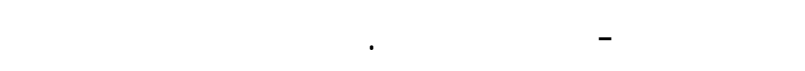

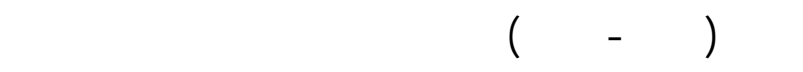

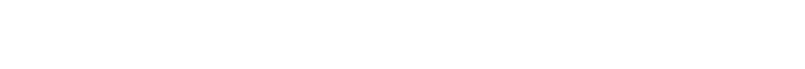

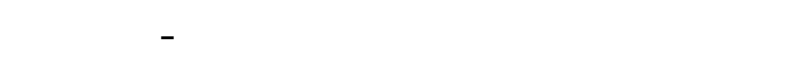

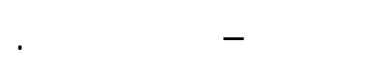

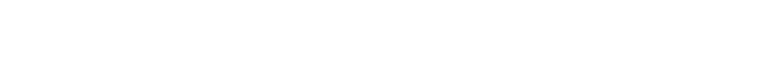

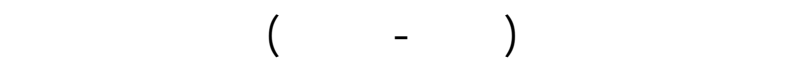

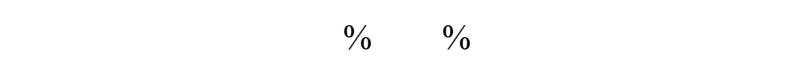

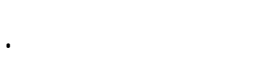

اثبتت هذه الدرلمة لن لستخدلم الاضلة إلزدوبة من الإل ــة

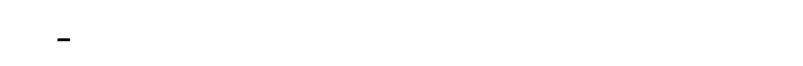

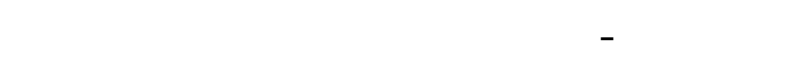

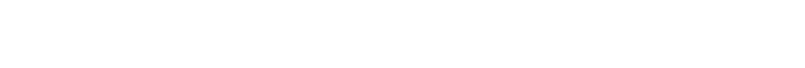
الصيفي.

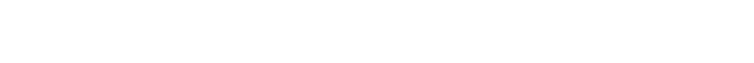

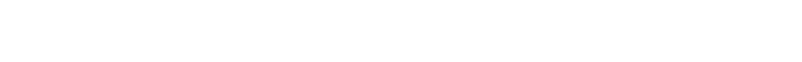

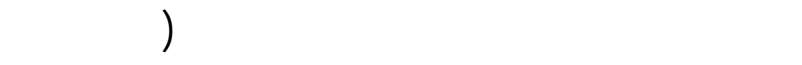

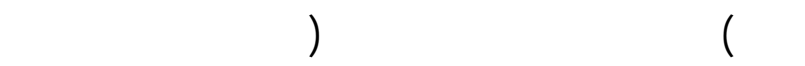

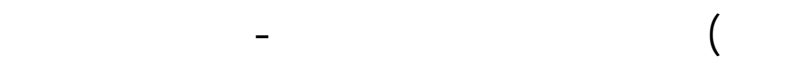
تزات المونيوم وسلفلت البوتلسيوه و هي كالتال (صفر صفر)، (

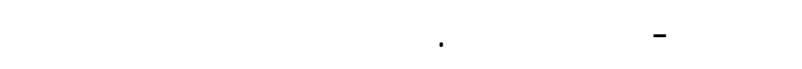

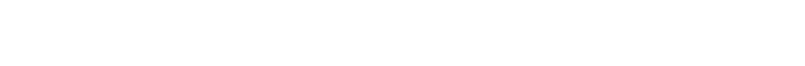

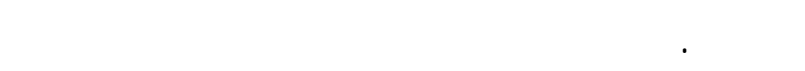

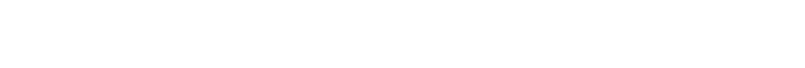

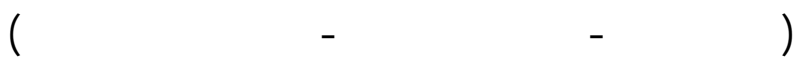

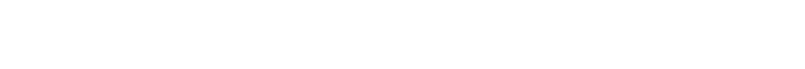

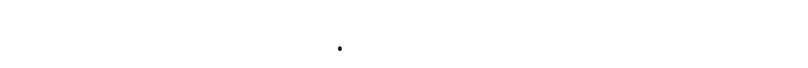

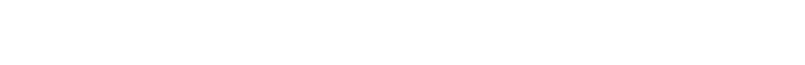

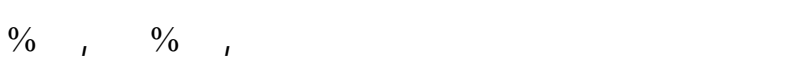
بالِّارة بالصف ليدي بلفور خلا مولي الدرلسة. وكذلك لظهر الصف فالور اعلى كنبة من الدرنت كلية الصجم.

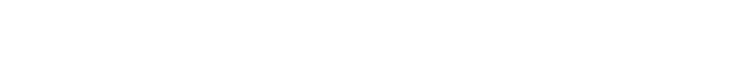

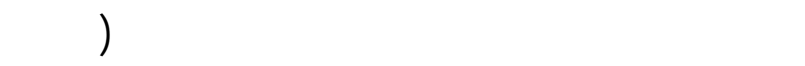

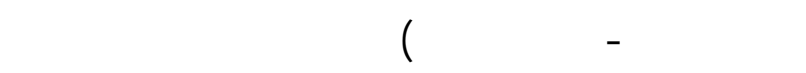

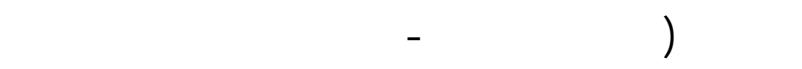

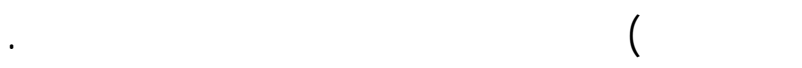

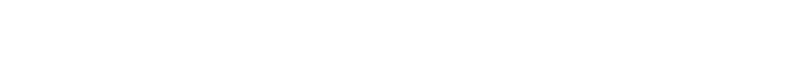

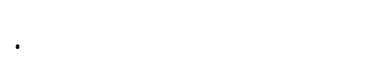

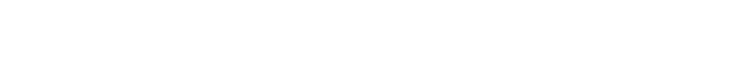

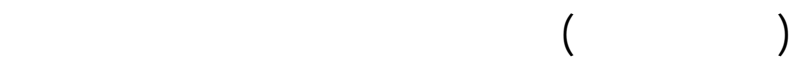

